\title{
Banks' total factor productivity growth in a developing economy: does globalisation matter?
}

\begin{abstract}
The paper provides, for the first time, empirical evidence on the impact of economic globalisation on bank total factor productivity in a developing economy. By employing the Malmquist Productivity Index method, we compute the total factor productivity of the Malaysian banking sector during 1998-2007. Examining different dimensions of economic globalisation, we find evidence supporting for greater trade and capital account restrictions and cultural proximity. On the other hand, personal contacts, information flows, and political globalisation seem to exert significant (negative) influence on banks' total factor productivity levels.
\end{abstract}

Keyword: Banks; Globalisation; Malmquist Productivity Index; Panel regression analysis; Malaysia 